\title{
Germ cell-less encodes a cell type- specific nuclear pore-associated protein and functions early in the germ-cell specification pathway of Drosophila
}

\author{
Thomas A. Jongens, Larry D. Ackerman, Jason R. Swedlow, ${ }^{1}$ Lily Yeh Jan, and Yuh Nung Jan ${ }^{2}$ \\ Howard Hughes Medical Institute and Departments of Physiology and Biochemistry, University of California, San Francisco, \\ California 94143-0724 USA; ${ }^{1}$ Graduate Group in Biophysics, University of California, San Francisco, California \\ 94143-0448 USA
}

\begin{abstract}
The maternally supplied pole plasm at the posterior pole of a Drosophila embryo contains determinants that specify both the germ-cell precursors (pole cells) and the posterior axis. One pole plasm component, the product of the germ cell-less gene, has been found to be required for specification of pole cells, but not posterior somatic cells. Mothers with reduced levels of gcl give rise to progeny that lack pole cells, but are otherwise normal. Mothers overexpressing $\mathrm{gcl}$, on the other hand, produce progeny exhibiting a transient increase of pole cells. Ectopic localization of $\mathrm{gcl}$ to the anterior pole of the embryo causes nuclei at that location to adopt characteristics of pole cell nuclei, with concurrent loss of somatic cells. We also present evidence indicating that the gcl protein associates specifically with the nuclear pores of the pole cell nuclei. This localization suggests a novel mechanism in the specification of cell fate for the germ line.
\end{abstract}

[Key Words: Germ line; germ cell-less; nuclear envelope; nuclear pore; mitotic asynchrony; cellular determination]

Received May 19, 1994; revised version accepted July 26, 1994.

Germ cells are unique in that they are the only cells that undergo meiosis and pass their genetic information to the next generation. In organisms ranging from worms to amphibians, the determinants for germ-cell specification are contributed solely by the maternal genome (for review, see Eddy 1975). In many of these organisms the germ-cell determinants are localized to an identifiable cytoplasm (germ plasm) that contains unique organelles (Beams and Kessel 1974; Eddy 1975). Although the process of germ plasm organization and some of its components have been characterized, very little is known about the molecular components of the germ plasm required for germ-cell determination in Drosophila (for review, see Lehmann and Rongo 1993; Wilson and Macdonald 1993).

In Drosophila the germ plasm (pole plasm) is localized to the posterior pole of the embryo and contains unique organelles referred to as polar granules (Mahowald 1962). The germ-cell precursors, or pole cells, form at the posterior pole of the embryo and engulf the contents of the pole plasm, including the polar granules (Mahowald 1971). This pole plasm is necessary and sufficient for both germ-cell specification and posterior axis specifica-

${ }^{2}$ Corresponding author. tion. Ectopic placement of pole plasm either through transplantation (Illmensee and Mahowald 1974; Niki 1986; Lehmann and Nüsslein-Volhard 1991) or through genetic manipulation (Ephrussi and Lehmann 1992) results in the ectopic formation of fully functional pole cells, as well as an ectopic posterior axis.

Analysis of mutations in the mother that result in defective posterior axis formation in the progeny (maternal effect mutations of the posterior group/ has identified nanos and pumilio, genes specifically required for posterior axis determination (Lehmann and Nüsslein-Volhard 1987, 1991; Barker et al. 1992; Macdonald 1992), as well as genes required for the formation of both posterior axis and pole cells. The latter include cappucino, spire, oskar, staufen, vasa, valois, tudor, mago nashi, and pipsqueak (Boswell and Mahowald 1985; Lehmann and NüssleinVolhard 1986; Schüpbach and Wieschaus 1986; Manseau and Schüpbach 1989; Boswell et al. 1991; Siegel et al. 1993). Mothers mutant for any of these genes produce embryos without detectable pole plasm.

Several of the genes identified by the posterior group mutants have been cloned and are known to be components of the pole plasm /vasa protein, Hay et al. 1988b; Lasko and Ashburner 1988; oskar mRNA and protein, Ephrussi et al. 1991; Ephrussi and Lehmann 1992; KimHa et al. 1991; Smith et al. 1992; staufen protein, St. 
Johnston et al. 1991; tudor protein, Bardsley et al. 1993; nanos mRNA and protein, Wang and Lehmann 1991; Ephrussi and Lehmann 1992; Smith et al. 1992). The posterior localization of these molecules appears sequentially and each new component requires the functions of all of the previous components for normal localization (for review, see Ding and Lipshitz 1993; Lehmann and Rongo 1993; Wilson and Macdonald 1993). Ultimately, this process leads to the localization of nanos and pumilio mRNAs, as well as the germ-cell determinants, to the posterior pole of the egg.

Both biological activities of the pole plasm (i.e., posterior axis specification and germ cell specification) are organized and activated by oskar. Ectopic localization of oskar mRNA to the anterior pole results in the formation of both functional pole cells and a posterior axis at the location of ectopic oskar expression (Ephrussi and Lehmann 1992). Overexpression of oskar during oogenesis results in the formation of additional pole cells, the formation of ectopic pole cell-like cells, and an expansion of the posterior axis (Ephrussi and Lehmann 1992; Smith et al. 1992).

Because pole plasm is capable of inducing pole cell formation at ectopic locations in the embryo, we presume that germ-cell determinants will be pole plasm components. The germ cell-less $(\mathrm{gcl})$ gene product has several characteristics expected for a component of the germ-cell specification pathway. Its posterior localization requires the function of all of the genes necessary for pole cell formation, it associates specifically with the nuclei that migrate into the pole plasm, and are incorporated into pole cells, and most important, reduction of maternal $g c l$ mRNA levels results in embryos that fail to form pole cells, but have a normal posterior axis (Jongens et al. 1992).

In this study we have addressed two questions concerning the role of $\mathrm{gcl}$ in the process of germ cell specification: (1) Is gcl protein sufficient to induce germ-cell formation? (2) What is the mechanism by which $\mathrm{gcl}$ carries out its function? To address the first question, we have generated transgenic flies in which gcl expression was altered. We show that increased levels of $\mathrm{gcl}$ in the embryo result in the formation of additional pole cells and that ectopically localized gcl initiates events similar to pole cell formation. To address the second question we have analyzed the subcellular localization of gcl using high-resolution three-dimensional wide-field microscopy and immunoelectron microscopy. Our analysis indicates that gcl protein is associated with the nuclear pores of the pole cells. We speculate on functions of $\mathrm{gcl}$ in the specification of the germ-cell lineage.

\section{Results \\ Overexpression of $\mathrm{gcl}$ results in the formation of additional pole cells}

Previously, we demonstrated that $g c l$ encodes a pole plasm component required for the formation of the pole cells (Jongens et al. 1992). To test whether $g c l$ is sufficient in promoting pole cell formation, we investigated the effects of overexpression of $\mathrm{gcl}$ on pole cell number. To increase the levels of maternally contributed $\mathrm{gcl}$ mRNA we constructed transgenic flies that contained the gcl-coding sequences and $3^{\prime} \mathrm{UTR}$, driven by the hsp83 promoter (Fig. 1A; see Materials and methods). Previously, the $h s p 83$ promoter has been shown to give
Figure 1. The overexpression of gcl leads to a higher concentration of $g c l$ mRNA and protein at the posterior pole. $(A)$ The hg construct used to overexpress $\mathrm{gcl}$ in the germ line (for construct details, see Materials and methods). $(B)$ Northern blot of RNA prepared from 0 - to 1 -hr embryos. (Lane 1) Control; (lane 2) hg 130; (lane 3) hg 27; (lane 4) hg 93. The blot was probed with two probes, one specific for $\mathrm{gcl}$ and one specific for $\alpha$-tubulin. The amount of $\mathrm{gcl}$ overexpression relative to the control for the hg lines is as follows: hg 27 (4.0fold), hg 130 (3.3-fold), and hg 93 (2.6-fold). $(C, D)$ Parallel whole-mount in situ hybridization using a probe specific for $\mathrm{gcl}$ mRNA was performed on $C$ control and $D$ hg 27 embryos. All embryos shown in this paper are oriented with the anterior pole to the left. $\{E, F\rangle$ Parallel immunocytochemistry was performed using anti-gcl antibodies on $E$ control and $F$ hg embryos; the arrows indicate the pole cells. The embryos in $C$ and $D$ are at the early cleavage stage and the embryos in $E$ and $F$ are at cellular blastoderm.
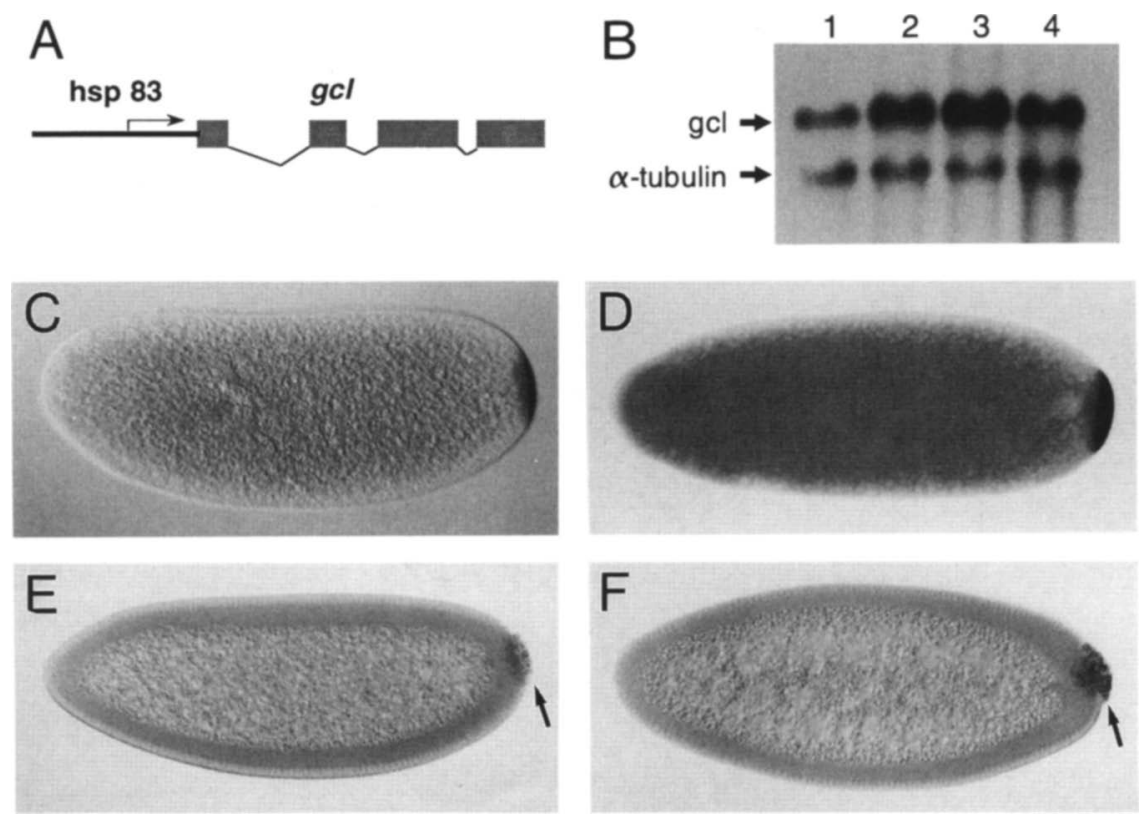
high level germ-line expression during oogenesis (Xiao and Lis 1989). We refer to this construct as hg $(\mathrm{hsp} 83 / \mathrm{gcl})$ and the embryos resulting from mothers containing it as "hg embryos." hg Embryos clearly have higher levels of gcl mRNA (Fig. 1B) at the posterior pole as well as an elevation in the background levels found throughout the rest of the embryo (Fig. 1, cf. D with C). A similar change in gcl protein distribution was observed, resulting in syncytial blastoderm embryos with an increase in the number and staining intensity of gcl-positive cells, which we presume are pole cells (Fig. 1, cf. F with E; see below). No effect on the localization of other pole plasm components (e.g., cyclin B mRNA, nanos mRNA, and vasa protein) was observed (not shown).

To determine whether embryos with elevated levels of $\mathrm{gcl}$ formed more pole cells, we counted pole cells at the time of their formation (interphase 11) and after they completed their initial divisions (cellular blastoderm, nuclear cycle 14) (Technau and Campos-Ortega 1986; Foe et al. 1993). To determine the number of pole cells formed initially, both control and hg embryos were fixed and stained with anti-vasa antibody and Hoescht stain. The vasa protein is known to be incorporated and maintained in the pole cells throughout embryogenesis and provides an independent marker for this cell type (Hay et al. 1990; Lasko and Ashburner 1990). The Hoescht stain specifically labels DNA and thus, allows staging of embryos with respect to the nuclear cycle (see Materials and methods). Pole cells were counted in embryos that were judged to be between interphase and metaphase of nu- clear cycle 11 , that is, the interval between pole cell formation and their first division (Foe et al. 1993). In the hg embryos $\sim 60-70 \%$ more pole cells formed initially compared to the control embryos (Fig. 2, Table 1). Using either anti-vasa- or anti-gcl-stained embryos for pole cell counts at the cellular blastoderm, we found that the difference between control and hg embryos was only $40 \%$ (Table 1 ). We conclude that the elevation of $\mathrm{gcl}$ levels increases the number of nuclei that initiate pole cell formation, but that these pole cells undergo fewer divisions or die before or during the formation of the cellular blastoderm.

In control blastoderm embryos, pole cells occasionally fall through the somatic cell layer, lose their plasma membrane, and leave behind a mass of chromatin that remains at least until the mid-gastrulation stage (Turner and Mahowald 1976), an effect that can be detected easily in Hoescht-stained embryos (Fig. 3A, bracket). The number of nuclei falling into the yolk mass in this manner was greater in hg (Fig. 3B, bracket) than in control embryos. The brackets in Figure 3 indicate DNA that we presume is derived from dying pole cells, as it and individual cells falling into the nuclear material stain with anti-gcl (Fig. 3C). These results suggest that more pole cells in the hg embryos die early in embryogenesis. Indeed, supernumerary pole cells were not detected in hg embryos at stage 14 when the pole cells coalesce in the embryonic gonad (Table 1). The formation of supernumerary pole cells and their subsequent loss, in early embryos owing to the overexpression of gcl, does not lead to
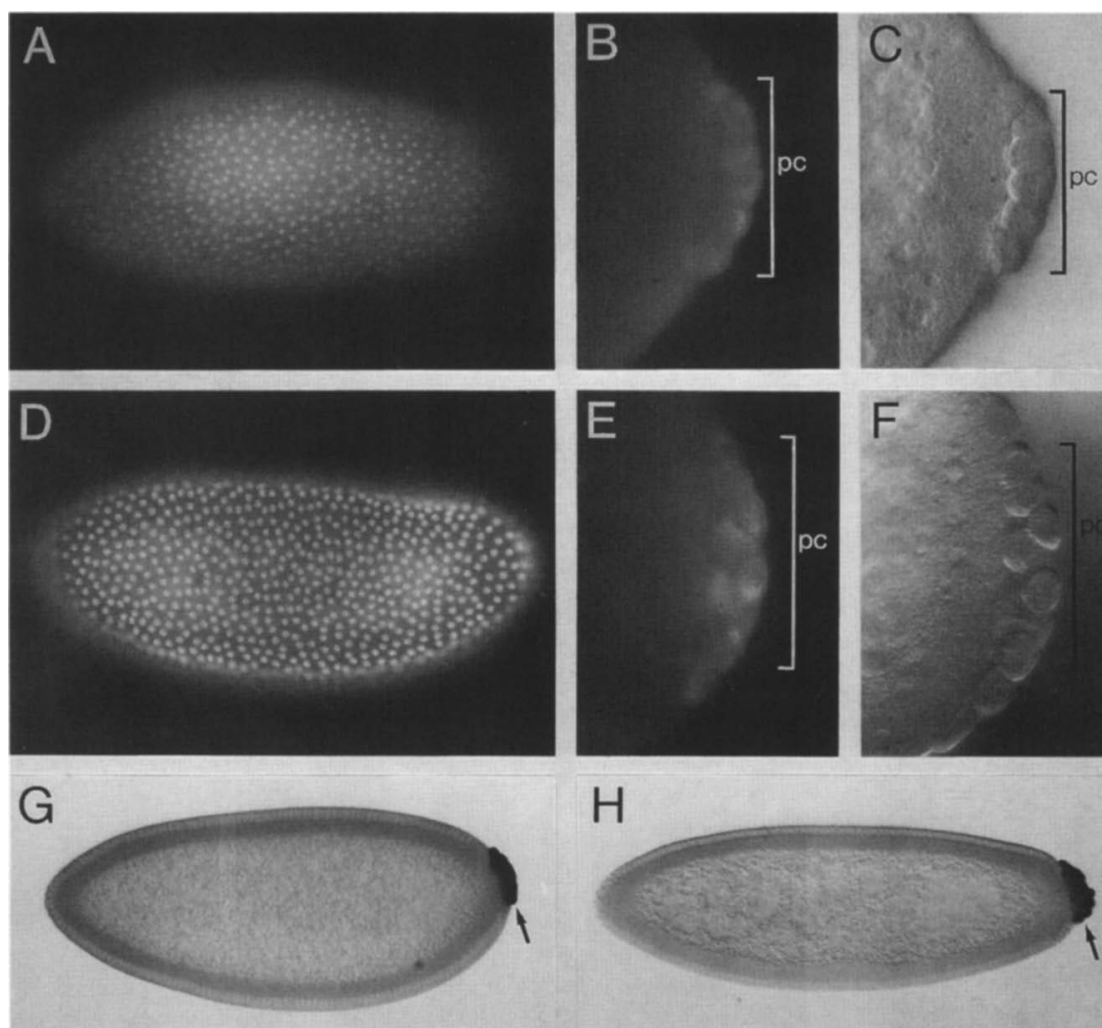

$\mathrm{H}$

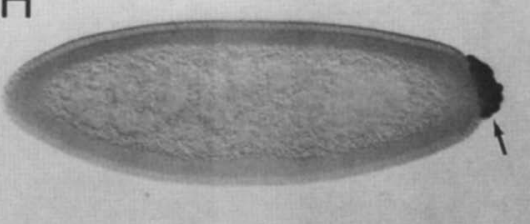

Figure 2. Overexpression of $g c l$ results in the formation of additional pole cells. $(A-$ $C)$ Control embryo and $(D-F)$ hg embryo at interphase of nuclear cycle 11 , shown with Hoescht-stained embryos $(A, D)$. The regions in the embryos where pole cells formed, as assayed by both anti-vasa staining $(B, E)$ and DIC optics $\{C, F\rangle$ is indicated with brackets labeled pc. $\{G, H\rangle$ Blastoderm stage embryos stained with anti-vasa antibody; pole cells indicated with arrows in the hg embryo $(H)$ and the control embryo $(G)$. 
Table 1. Summary of the pole cell counts

\begin{tabular}{|c|c|c|c|c|}
\hline Line & Stage & $\begin{array}{l}\text { Average number } \\
\text { of pole cells }\end{array}$ & $\begin{array}{l}\text { Antibody used } \\
\text { in assay }\end{array}$ & $\begin{array}{l}\text { Percentage of } \\
\text { the host line }\end{array}$ \\
\hline $\mathbf{w}^{-}$ & interphase 11 & $11.6 \pm 0.5$ & anti-vasa/Hoescht & 100.0 \\
\hline hg27 & interphase 11 & $19.9 \pm 0.5$ & anti-vasa/Hoescht & 172.0 \\
\hline hg130 & interphase 11 & $19.0 \pm 0.3$ & anti-vasa/Hoescht & 164.0 \\
\hline $\mathbf{w}^{-}$ & blastoderm & $28.2 \pm 0.7$ & anti-vasa & 100.0 \\
\hline$w^{-}$ & blastoderm & $26.2 \pm 0.9$ & anti-gcl & 100.0 \\
\hline hg93 & blastoderm & $34.8 \pm 1.2$ & anti-vasa & 123.0 \\
\hline hg93 & blastoderm & $34.5 \pm 1.3$ & anti-gcl & 132.0 \\
\hline hg27 & blastoderm & $37.8 \pm 1.0$ & anti-vasa & 134.0 \\
\hline hg27 & blastoderm & $36.0 \pm 0.9$ & anti-gcl & 137.0 \\
\hline w- & blastoderm & $27.5 \pm 0.7$ & anti-vasa & 100.0 \\
\hline hg130 & blastoderm & $40.6 \pm 0.9$ & anti-vasa & 148.0 \\
\hline $\mathbf{w}^{-}$ & stage 14 & $21.5 \pm 0.5$ & anti-vasa & 100.0 \\
\hline hg93 & stage 14 & $20.9 \pm 0.6$ & anti-vasa & 97.0 \\
\hline hg27 & stage 14 & $21.4 \pm 0.7$ & anti-vasa & 99.5 \\
\hline
\end{tabular}

Pole cell counts (mean \pm S.E.M.) on control ( $w-1$ and hg embryos, using anti-vasa or anti-gcl to mark pole cells as indicated. The determination of the stage of the embryo and the number of pole cells is described in Materials and methods. Line spaces separate four different counting experiments. Pole cells were counted for at least 20 embryos at interphase 11 , or at least 50 embryos at both the cellular blastoderm stage and at stage 14.

any detectable developmental defects. The resulting hg embryos develop into morphologically normal and fertile adults.

\section{Overexpression of $\mathrm{gcl}$ in early embryos leads}

to a distinct nuclear morphology and earlier onset of mitotic asynchrony of the pole bud nuclei

Pole cell nuclei are the first nuclei in the embryo to divide asynchronously. This asynchrony generally begins after nuclear cycle 10 when pole cells are formed (Foe et al. 1993). Because pole cells divide from 0-2x after their formation (Technau and Campos-Ortega 1986), some pole cell nuclei stop dividing after nuclear cycle 10, whereas somatic nuclei go through 13 cycles of nuclear division before the onset of asynchronous divisions.

In hg embryos, we observed two distinct properties of the pole bud nuclei. First, during interphase of nuclear cycles 9 and 10, the pole bud nuclei in hg embryos were generally much smaller in size than the corresponding somatic nuclei within the same embryo [the majority of the pole bud nuclei were $\leqslant 20 \%$ smaller in diameter than somatic nuclei in 34 of $43(79 \%)$ embryos] (Fig. 4, cf. $\mathrm{E}-\mathrm{H}, \mathrm{G}$ with F). This difference in size between pole bud and somatic nuclei was seen at a lower frequency in control embryos [the majority of pole bud nuclei were $20 \%$ smaller in diameter than somatic nuclei in only 15 of $46(32 \%)$ embryos, a statistically significant difference, $z=4.4, \alpha<0.01$ (see Materials and methods; Fig. 4, cf. A-D and C with B)]. The second property we observed was that the pole bud nuclei in the hg embryos were sometimes delayed in nuclear cycle 9 but almost always delayed in nuclear cycle 10 with respect to the somatic nuclei (Fig. 4L-N) and the pole bud nuclei in control embryos (Fig. 4I-K). In 24 of $29(83.0 \%)$ hg embryos examined, at metaphase to telophase of cycle 10, the majority of the pole bud nuclei were obviously delayed, whereas in only 5 of $34(15.0 \%)$ control embryos was this observed, a statistically significant difference, $z=5.44$, $\alpha<0.01$ (see Materials and methods). These two properties may be interrelated in that the delays in mitosis would cause delayed entry into interphase. Because nuclei grow in size during interphase, those nuclei entering interphase later would appear smaller in size.

Ectopic localization of $\mathrm{gcl}$ mRNA leads to events that mimic the pole cell nuclei behavior during pole cell formation

Because we found that higher $\mathrm{gcl}$ levels result in an initial increase in pole cell number, we investigated whether $\mathrm{gcl}$ activity would initiate pole cell formation in an ectopic position. In an attempt to localize $g c l$ mRNA to the anterior pole of the embryo, we replaced the $3^{\prime}$ UTR of $g c l$ with the anterior localization signal and polyadenylation signal of bicoid mRNA (Macdonald and Struhl 1988; see Materials and methods), using a design analogous to ones that have been used previously to mislocalize oskar and nanos mRNAs to the anterior pole of the embryo (Ephrussi and Lehmann 1992; Gavis and Lehmann 1992). Again germ-line expression was obtained using the hsp 83 promoter. This construct is called hgb ( $h s p 83 ; g c l ; b c d ;$ Fig. 5A). The progeny from transgenic mothers containing it are referred to as "hgb embryos."

Mislocalization of $g c l$ mRNA and protein to the anterior pole was evident in the hgb embryos. We found $g c l$ mRNA and gcl protein at both posterior and anterior poles of the embryo. The $g c l$ mRNA and protein at the 

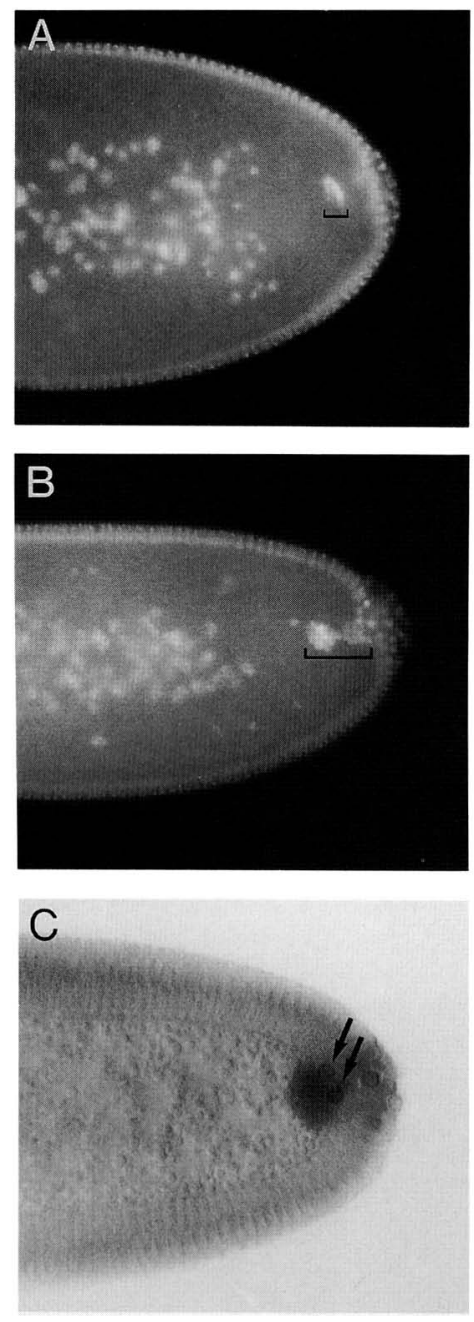

Figure 3. Increased loss of pole cells in the hg embryos. $\{A, B\}$ Posterior halves of control $(A \mid$ and hg $(B)$ blastoderm-stage embryos stained with Hoescht. DNA presumably from dying pole cells is denoted with brackets. $|C|$ The posterior half of an early gastrula embryo stained with anti-gcl. Arrows indicate pole cells that have fallen through the somatic cell layer. Note the diffuse gcl staining adjacent to the pole cells that have fallen in and are presumably dying. The majority of the pole cells in this embryo have migrated dorsally and are not visible in this focal plane.

anterior pole had a distribution similar to that previously described for bicoid mRNA and protein (Fig. 5B,C; Berleth et al. 1988; Drevier and Nüsslein-Volhard 1988). The gcl protein at the anterior pole was detected sooner and at much higher levels than at the posterior pole (Fig. $5 \mathrm{C}, \mathrm{E})$. Interestingly, the subcellular localization of $\mathrm{gcl}$ protein in the anterior pole was similar to that at the posterior: Both associated with the nuclear envelope in a punctate pattern (Fig. 5D,F; see below).

To test the effect of ectopic localization of gcl protein, we fixed and stained embryos from hgb lines with antigcl antibody and examined them using differential interference contrast (DIC) optics for the formation of ectopic pole cells at the syncytial and cellular blastoderm stages. The anterior nuclei displayed properties in common with pole cells, including the appearance of pole bud-like structures, the shape of the nuclei, and the timing of nuclear divisions, as described below.

The first effect of ectopic $\mathrm{gcl}$ was detected after the nuclei in the syncytial blastoderm reached the surface of the embryo. In the wild-type embryo, these nuclei induce the formation of buds, protuberances in the plasma membrane (Foe et al. 1993), and the buds that form at the posterior pole, the "pole buds", are more pronounced than those elsewhere in the embryo. In hgb embryos the buds at the anterior pole were much more pronounced than those in the control embryos (Fig. 6, cf. B with A), and resembled the pole buds that appear at interphase of nuclear cycle 9 . This pronounced ectopic budding was present in nuclear cycles 11 and 12. Unlike at the posterior pole, these ectopic buds did not pinch off to form pole cells.

The second unusual feature of the anterior nuclei, which appeared after the onset of ectopic budding, was the timing of nuclear division in the hgb embryos. In the wild-type embryo, only the pole cell nuclei divide asynchronously from the somatic nuclei in cycles 11,12 , and 13. In comparison with control embryos and the more posterior somatic nuclei in hgb embryos, the anterior nuclei in the hgb embryos, like the pole bud nuclei during cycle 10, were either smaller in size during interphase or delayed in the other stages of the nuclear cycle (Fig. 6C-H). These effects were observed in some embryos at nuclear cycle 12, and in all of the embryos by cycle 13. To confirm the observation seen in the fixed embryos, we analyzed the nuclear cycles in living embryos using DIC optics and charge-coupled device (CCD) time-lapse photography (see Materials and methods). In all five hgb embryos observed, distinct delays ( $2-4 \mathrm{~min}$ ) into the entry of mitosis 12 and 13 were observed for the anterior nuclei, when compared to the timing of the rest of the somatic nuclei. Such a delay was not observed in five control embryos. In fact, in the control embryos, mitosis was initiated near the anterior and posterior poles, consistent with the observations of Foe et al. (1993).

The third pole cell-like characteristic was the shape of the nuclei. It is known that the germ-line nuclei retain a distinct round shape throughout embryogenesis (Underwood et al. 1980), whereas the somatic nuclei elongate and become more cylindrical during interphase of cycle 14 , before the initiation of cellularization (Fullilove and Jacobson 1971; Foe et al. 1993). The anterior nuclei in the hgb embryos retained a round shape during interphase 14, clearly different from the more posterior nuclei that had undergone elongation (Fig. 6I-K). During the invagination of the membrane furrows, which normally separate the somatic nuclei, many of the anterior nuclei in the hgb embryos were displaced into the center of the embryo (Fig. 6I). Those that were incorporated into cells still retained a round shape (Fig. $6 \mathrm{~K}$ ).

The ectopic localization of $g c l$ mRNA did not result in the ectopic localization of other pole plasm components 

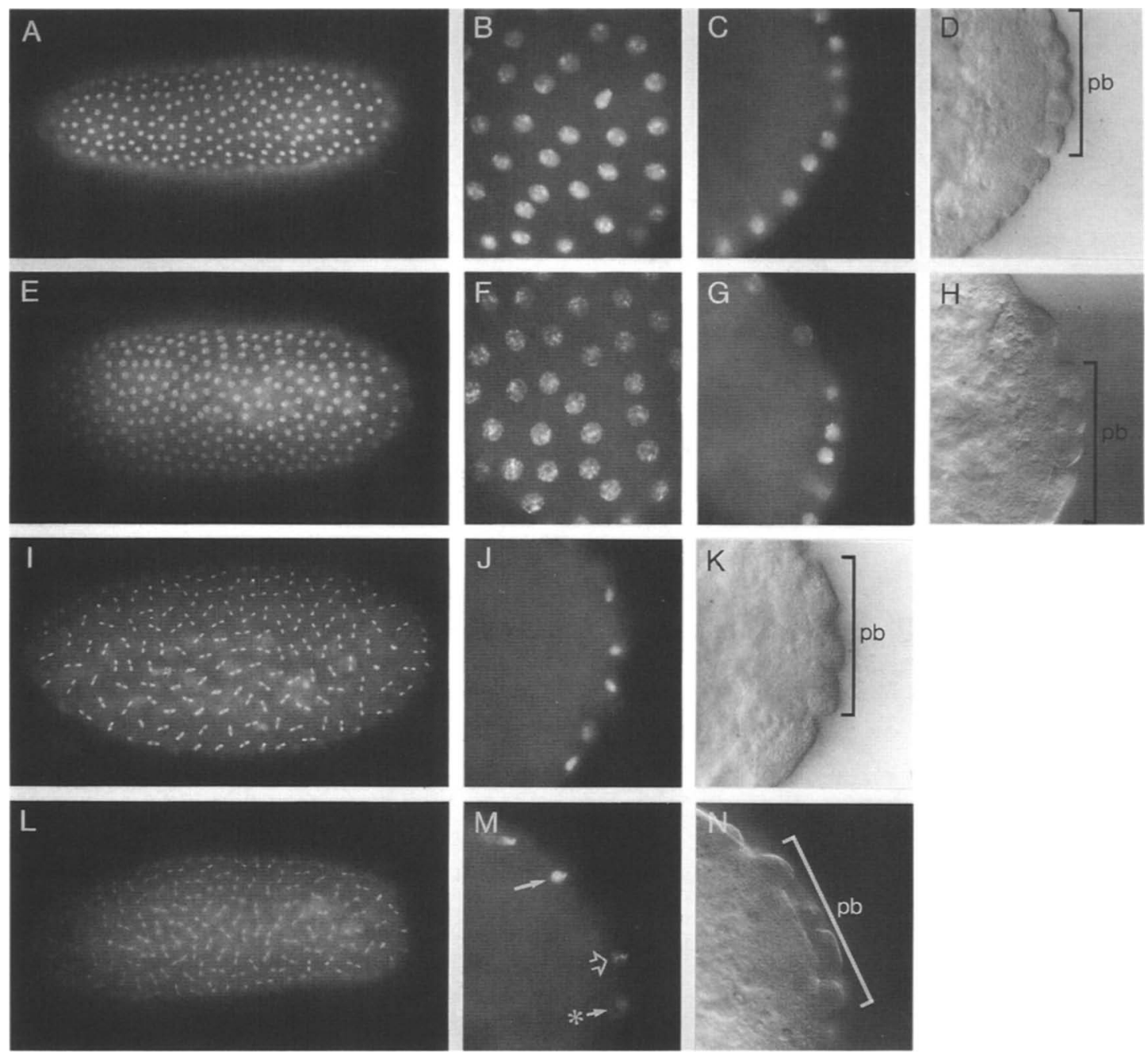

Figure 4. The pole bud nuclei in the hg embryos are more compact during interphase and are mitotically delayed. $A-D$ and $E-H$ are a control and an hg embryo, respectively, at interphase of nuclear cycle 10 (the hg embryo is at a later stage of interphase than the control embryo; therefore its nuclei are larger). $(A, E)$ Surface nuclei stained with Hoescht show comparison of nuclear density, (i.e., nuclear stage). $B, C$ and $F, G$ are higher magnification photos showing somatic $(B, F)$ and posterior pole $(C, G)$ nuclei. The pole buds, visible in the DIC images $(D, H)$, are indicated with brackets labeled pb. $I-K$ and $L-N$ are a control and an hg embryo, respectively, at anaphase of nuclear cycle 9. I,L show surface nuclei stained with Hoescht and allow determination of nuclear stage. $/$ and $M$ show Hoescht-stained posterior pole nuclei, with the pole buds seen in the DIC images $(K, N)$ indicated by brackets labeled pb. All of the nuclei in the control embryo $(I, N)$ are at anaphase of cycle 9 . Mitotically delayed nuclei in the hg embryo $(M)$ are in prometaphase (arrow), metaphase (open arrow), or early prophase (slightly out of focus) (asterisk and arrow).

tested, including vasa protein, nanos mRNA, and cyclin $B$ mRNA (not shown). This result is consistent with our previous studies that indicated that $g c l$ function is not required for pole plasm assembly, and suggests that the effects observed at the anterior pole are attributable solely to the concentration of $\mathrm{gcl}$ and not to that of other pole plasm components.

The results described above indicate that although the anterior nuclei in the hgb embryos behaved like pole cell nuclei, they did not go on and form ectopic pole cells. One possible explanation was that the anterior axis morphogens interfered with pole cell formation. Normally, pole cells form at the posterior pole where nanos activity represses translation of hunchback mRNA /Wharton and
Struhl 1991), thus preventing any exposure to anterior morphogens. Even when anteriorly localized oskar causes anterior pole cell formation in a nanos ${ }^{17}$ (hypomorphic) mutant background, the remaining nanos protein is also mislocalized, becomes highly concentrated in the ectopic pole plasm, and in fact, is incorporated into the ectopic pole cells when they form (Ephrussi and Lehmann 1992). Thus, the levels of the anterior morphogens may need to be reduced sufficiently to allow pole cell formation. To test this possibility, we placed the hgb construct in each of three mutant backgrounds that eliminated the anterior axis morphogens, namely $b c d^{E 1 /}$ $b c d^{E 1}$ (Frohnhöfer and Nüsslein-Volhard 1986); Bic$D^{\text {EIII48 } / B i C D^{7134}}$ (Molher and Wieschaus 1986); and an- 
A
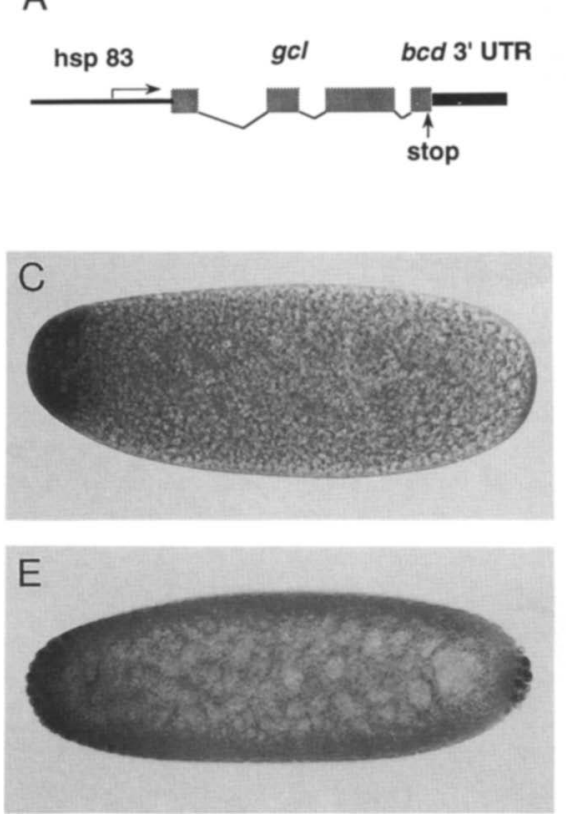
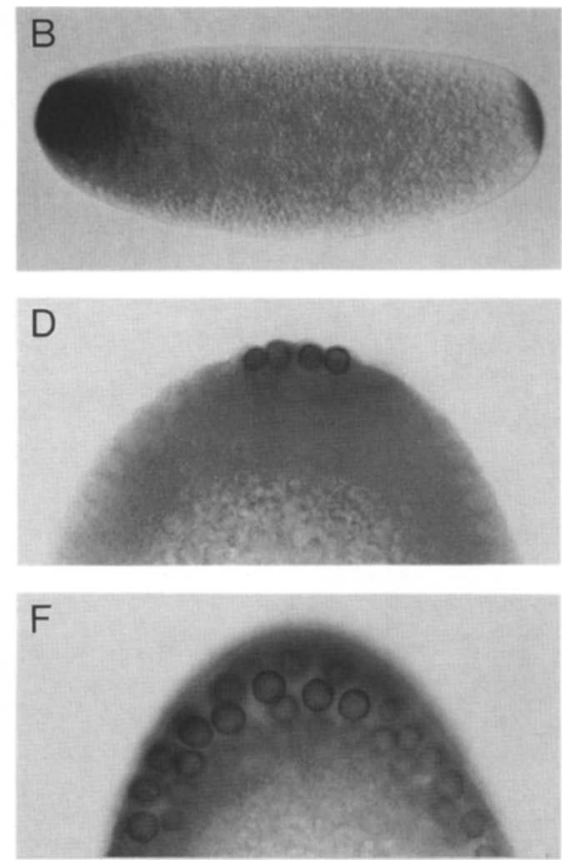

Figure 5. Ectopic expression of $g c l$ mRNA and protein using the anterior localization signal of bicoid. (A) The hgb construct with genomic sequences of the gcl-coding region fused to the $3^{\prime}$ UTR of bicoid, driven by the $h s p 83$ promoter. $(B)$ Whole-mount in situ hybridization of an hgb embryo using a probe specific for $\mathrm{gcl}$ mRNA. $|C, E|$ Whole-mount immunocytochemistry of hgb embryos using anti-gcl antibodies. $(C)$ An early cleavage embryo with detectable gcl protein in the anterior pole before gcl can be detected in the pole plasm. (E) A syncytial blastoderm-stage embryo with gcl protein detectable at both poles. $(D, F)$ High magnification of $\mathrm{gcl}$ staining in an hgb embryo. The subcellular localization of gcl protein in the pole cells $(D)$ and on the anterior nuclei $(F)$ is perinuclear. teriorly localized nanos (Gavis and Lehmann 1992). We found no enhancement or suppression of ectopic $\mathrm{gcl}$ activity, indicating that factors other than those that eliminate the anterior morphogens were needed for pole cell formation.

We also tested whether the delocalization of pole plasm components could raise their concentration throughout the rest of the embryo, and increase the likelihood of ectopic pole cell induction by $\mathrm{gcl}$. Among the posterior group mutants we tested (cappucino, spire, oskar, tudor, staufen, and vasa), no enhancement toward pole cell formation was observed.

\section{Ectopic localization of $\mathrm{gcl}$ affects the formation of anterior structures}

Transgenic females carrying the hgb construct were sterile. Their resulting offspring died either during embryogenesis or as first instar larvae and had anterior defects ranging from malformed mouth hooks and loss of anterior gut, to the loss of the mouth hooks, anterior gut, pharynx, and part of the anterior cuticle (Fig. 6M,N). The loss of anterior structures may be explained in part by an early loss of somatic cells at the anterior of the blastoderm, as many of the nuclei in the anterior pole fell into the center of the embryo (Fig. 6I). However, some of the hgb embryos had only a few nuclei that failed to cellularize, and yet all of the hgb embryos lacked some anterior structures. This indicates that some of the cells that form at the anterior pole of the hgb embryos fail to adopt their normal cell fate, or that they died after cellularization. We believe that the missing anterior structures in these embryos are probably caused by later cell loss as we did not detect any changes in the early embryonic fate map. No change in the distribution of hunchback (maternal and zygotic) and knirps expression was detected in hgb versus control embryos (not shown).

gcl protein localizes near the nuclear pores of the pole cell nuclei

The gcl protein is localized specifically to the pole cell nuclei in the blastoderm embryo (Jongens et al. 1992). Immunofluorescence in conjunction with high-resolution three-dimensional wide-field microscopy, and immunoelectron microscopy, indicated that the subcellular distribution of $\mathrm{gcl}$ is consistent with an association to the nuclear pores of the germ-cell precursors.

All antibodies directed to proteins of the nuclear pore (Davis and Blobel 1986; Aris and Blobel 1989; Davis and Fink 1990; Nehrbass et al. 1990; Wente et al. 1992) and wheat germ agglutinin, which is likely to bind to nucleoporins containing O-linked oligosaccharides (Finlay et al. 1987), give a distinct punctate perinuclear staining pattern when examined by immunofluorescence. This punctate perinuclear pattern is similar to the staining pattern observed with anti-gcl antibodies. To highlight the punctate staining pattern of gcl, we compared its distribution with that of a B-type lamin in doubly stained embryos (Fig. 7). Previously, B-type lamins have been shown to be a component of the nuclear lamin that is continously distributed along the inner surface of the nuclear envelope, except near nuclear pores (Dingwall and Laskey 1992; Belmont et al. 19931. Although the anti-gcl antibody was highly concentrated on the pole cell nuclei (Fig. 7), as opposed to the general staining by the anti-lamin antibody of both germ-line and somatic nuclei (Fig. 7 ), both staining patterns were perinuclear. The anti-gcl pattern, however, was less continuous along 
Figure 6. Ectopically localized $g c l$ induces characteristics of pole cell nuclei at the anterior pole. $(A, B)$ Control $(A)$ and an hgb $(B)$ embryo at the same stage; pole cells are indicated with open arrows and ectopic anterior buds of the hgb embryo are indicated with arrowheads in $B .(C-E)$ An interphase 12 hgb embryo stained with Hoescht; surface nuclei are shown in $C$, the compact anterior nuclei are shown in $D$, and corresponding somatic nuclei from a more posterior position shown in $E$. $(F-H)$ An hgb embryo at telophase 13 stained with Hoescht; surface nuclei are shown in $F$, the asynchronous anterior nuclei are shown in $G$, and corresponding synchronous nuclei from a more posterior position of the same embryo are shown in $H$. $(I)$ The anterior two-thirds of an hgb embryo stained with gcl antibody; some of the nuclei that have fallen in are indicated with arrowheads. Note that nuclei that stain positive for $\mathrm{gcl}$ are round in shape, whereas the unstained nuclei are elongated. $(J, K)$ Nomarski images of the anterior poles of a control $(J)$ and an hgb $(K)$ embryo after cellularization. The anterior nuclei in the control embryo are elongated in shape, whereas the corresponding nuclei in the hgb embryo are still round. $(L-N)$ Cuticles of control $(L)$ and hgb $(M, N)$ progeny. $M$ shows the anterior pole of an hgb first instar larva with the mild phenotype, compare mouth hooks (mh) to those in $L$. $N$ shows the severe phenotype of an hgb embryo, with a hole in the cuticle (ch) and missing mouth hooks. (T1, T2, and T3) Thoracic segment 1, 2, and 3; abdominal segments $1-8$ are bracketed (A1-A 8$)$.
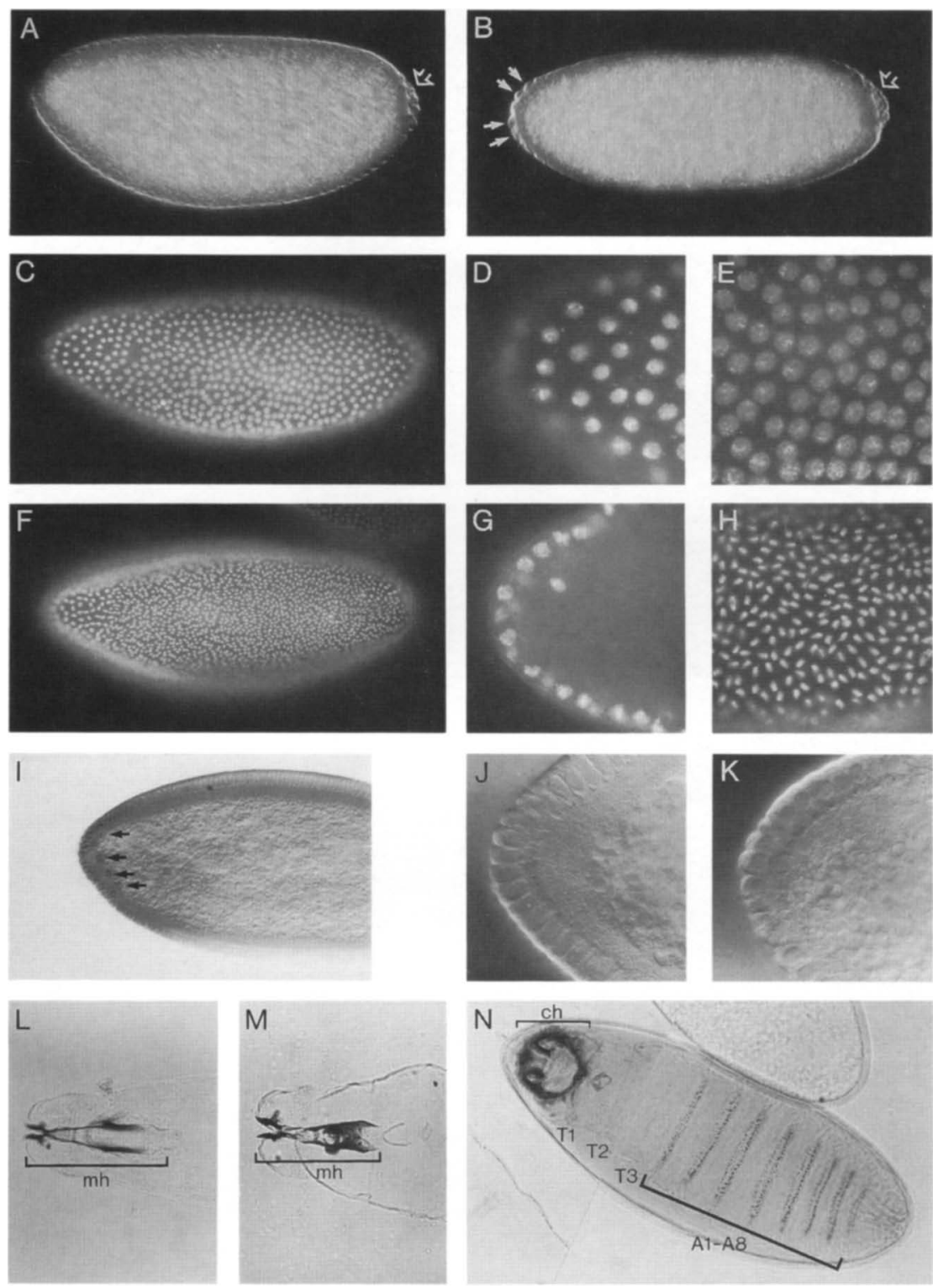

the nuclear envelope than the pattern obtained with the anti-lamin antibody (Fig. 7) and the two proteins do not colocalize on the surface of the pole cell nuclei (Fig. 7, see legend), consistent with the hypothesis that $\mathrm{gcl}$ is present at nuclear pores.

To observe the subcellular localization of $\mathrm{gcl}$ protein in more detail, we used immunoelectron microscopic analysis of blastoderm-stage embryos labeled with antigcl antibody and a gold-conjugated secondary antibody (see Materials and methods). The gcl protein was localized primarily to the nuclear envelope and showed discontinuous distribution (Fig. 8A). Some gcl protein was also detected throughout the cytoplasm, as well as within the nucleus.

At higher magnification, most of the gcl protein associated with the nuclear envelope was found on the nu- cleoplasmic side and was almost always near an identifiable nuclear pore complex (NPC) (Fig. 8B,C). NPCs were identified as dark staining regions that spanned the distance between the inner and outer membrane of the nuclear envelope (Fig. 8B,C, short arrows). The observed location of $\mathrm{gcl}$ with respect to the NPC was variable. Sometimes gcl immunoreactivity was directly adjacent to the nucleoplasmic surface of the NPC, but in most cases it was located within $100 \mathrm{~nm}$ of one side of the NPC. Occassionally gcl protein was found in regions without an identifiable NPC (Fig. 8C, open triangles) and was not always associated with identifiable NPCs (Fig. $8 \mathrm{~B}, \mathrm{Cl}$. We presume that this is attributable to separation of the NPC from gcl protein during sectioning, given that gcl protein is often located just to the side of an NPC and that the sections were only $100 \mathrm{~nm}$ thick. 


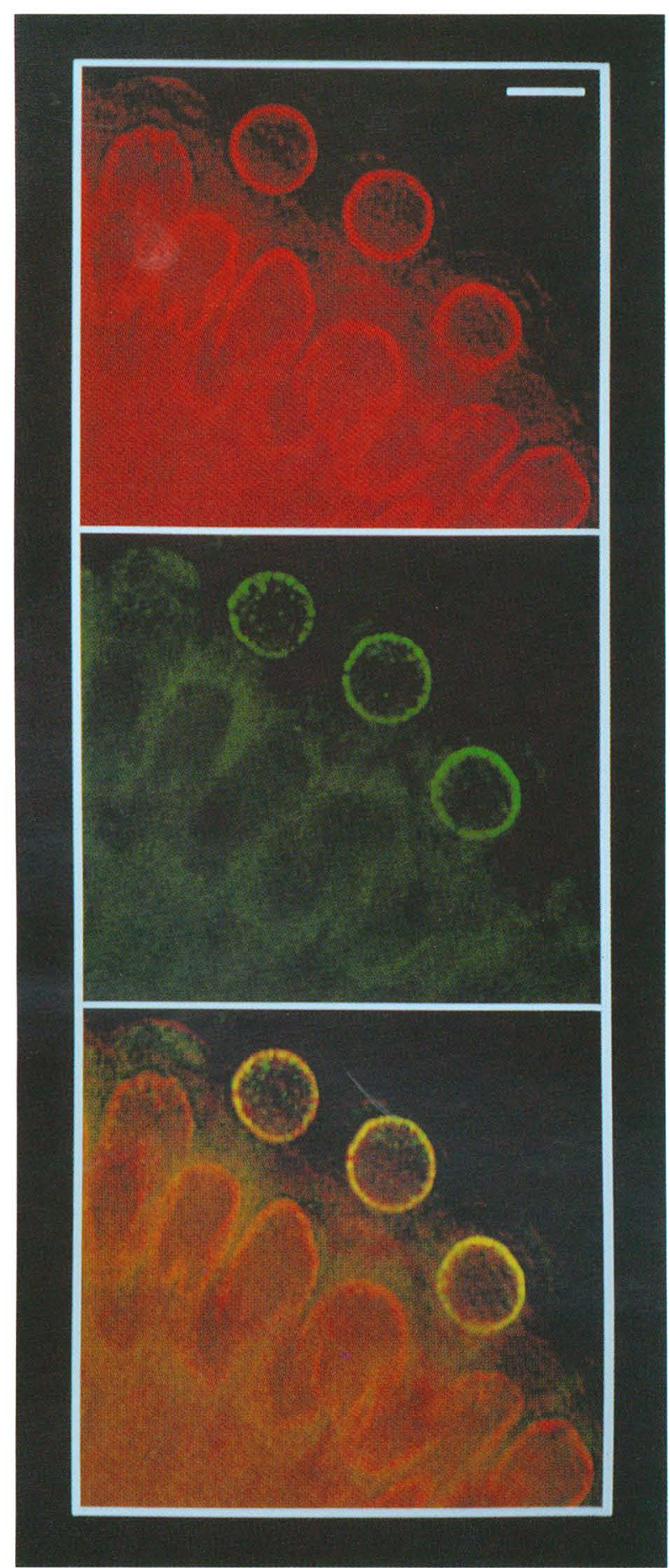

\section{Discussion}

Our results derived from overexpression and ectopic localization of $\mathrm{gcl}$ products suggest that $\mathrm{gcl}$ can initiate events in germ-cell formation, but that there is a requirement of at least one other localized factor for complete pole cell determination. The apparent localization of $\mathrm{gcl}$ to the nuclear pores of the germ-cell precursors suggests a novel mechanism by which the germ-cell fate is determined.
Figure 7. High-resolution CCD image showing that the subcellular distribution of gcl is distinct from lamin protein. A blastoderm-stage embryo was stained with both anti-lamin and anti-gcl antibodies and visualized using fluorescently conjugated secondary antibodies in conjuction with high-resolution three-dimensional wide-field microscopy. Shown is a projection of optical sections taken from the posterior pole of a blastoderm embryo, which include the periphery and top surface of three pole cell nuclei (round nuclei). The distribution of B-type lamin protein, which is present in all nuclei, is shown at the (top) (red). The gcl protein distribution, which is most concentrated on the pole cell nuclei, is shown in the middle (green). Staining, which appears to localized within the nucleus, is in fact mostly derived from sections that graze the nuclear surface. The superimposition of both signals is shown at the bottom, with the anti-gcl signal indicated in green and the anti-lamin distribution shown in red. Overlapping signals are shown in yellow. Note the signal derived from the grazing sections suggests little overlap between gcl and lamin protein distributions on the nuclear surface.

$\mathrm{gcl}$ is a limiting component of the pole plasm and is capable of initiating the germ-cell specification pathway

The number of pole cells that form initially in an embryo at the syncytial blastoderm stage is determined by the number of nuclei that reach the posterior pole and the percentage of these that are incorporated successfully into pole cells. As the elevation of $\mathrm{gcl}$ has no detectable effects on nuclear migration, more of the nuclei that reached the posterior pole must have ended up in pole cells. Thus, the increase of the initial number of pole cells due to an elevation of $\mathrm{gcl}$ levels indicates that $\mathrm{gcl}$ is capable of initiating or assisting in events that result in the formation of pole cells and that it is a limiting pole plasm component with respect to this process. This is consistent with our previous studies that also demonstrate that the number of pole cells initially formed is dependent on gcl levels (Jongens et al. 1992).

It seems likely that $g c l$ is involved in the pathway to initiate germ-cell specification for several reasons. First, gcl protein specifically associates with those nuclei that will become germ-line nuclei, before the formation of pole cells or pole buds (Jongens et al. 1992). In addition, results obtained in this study suggest that $\mathrm{gcl}$ can initiate the specification of germ cells: (1) the early onset of mitotic asynchrony when $\mathrm{gcl}$ levels were elevated; and $(2)$ the ectopic initiation of pole cell-like characteristics when the gcl product was localized ectopically. In the wild-type embryos, the onset of mitotic asynchrony and establishment of germ-cell fate occur at the same time, when the pole cells form (Technau and Campos-Ortega 1986; Foe et al. 1993). A similar correlation between the cell cycle and cell fate determination has been documented for other cell types (Marsh et al. 1991; Olson 1992). Hence, the earlier onset of mitotic asynchrony for the pole bud nuclei may indicate an earlier onset of germ-cell fate specification caused by overexpression of gcl.

Similar mitotic asynchrony, as well as the round shape and large buds characteristic of pole cell nuclei, can be 

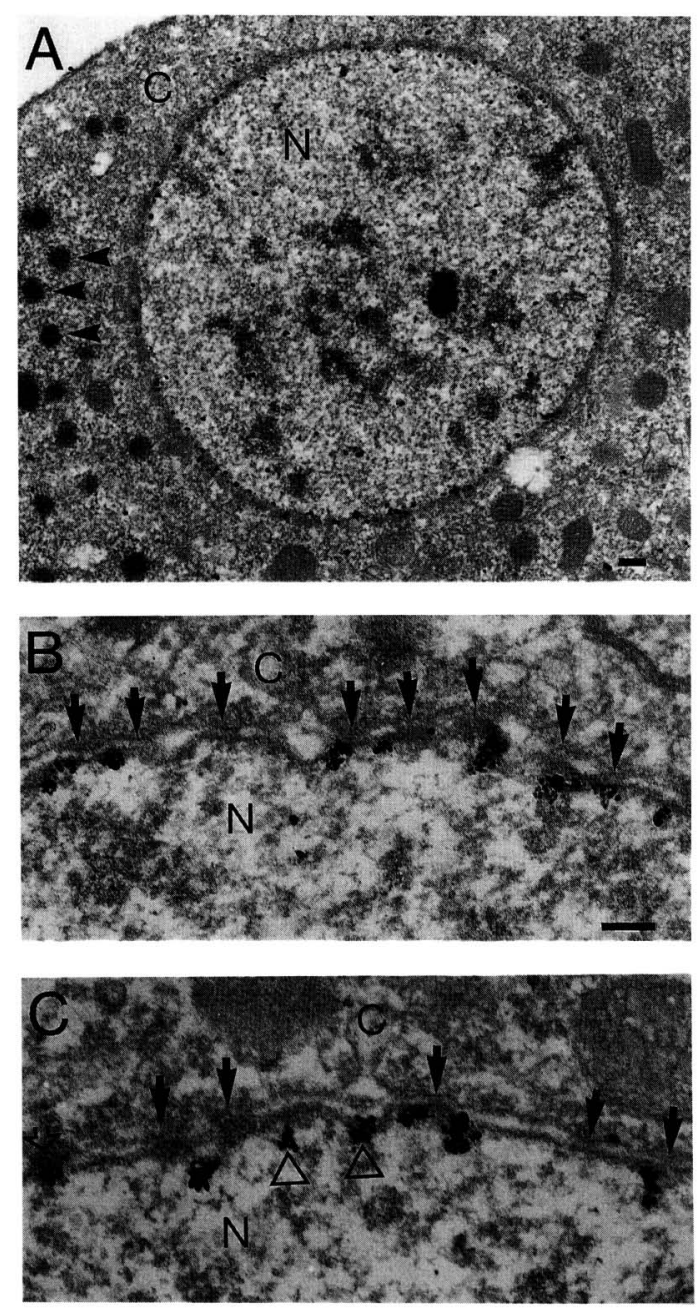

Figure 8. Immunoelectron microscopy of blastoderm-stage embryos showing the distribution of gcl protein in a single pole cell $(A)$ and along the nuclear envelope of a pole cell nucleus $(B, C)$. The location of gcl protein is seen as black dots. (N) Nucleoplasm; $(C)$ cytoplasm. In $A$ arrowheads indicate polar granules. In $B$ and $C$ nuclear pores are indicated with arrows; (an open arrow indicates a tangential view of a nuclear pore, $(\Delta) \mathrm{gcl}$ protein that is not located near an identifiable NPC. Bar, $200 \mathrm{~nm}$ $(A), 100 \mathrm{~nm}(B) . B$ and $C$ are at the same magnification.

induced by $g c l$ at the anterior pole. These nuclei either fail to cellularize or fail to give rise to anterior structures, indicating that they have adopted a different fate. Although the earlier mitotic and morphologic alterations of the nuclei before cellularization suggest that they may confer the fate of pole cells, the absence of early zygotic pole cell markers prevents us from further testing this possibility at the anterior pole on the affected cells. Nonetheless, the ectopic expression of $g \mathrm{cl}$ at the anterior pole clearly causes nuclei in the syncytial blastoderm to take on characteristics of pole cell nuclei and prevents the cells that form subsequently at this location from adopting their normal cell fate.

Although the induction of pole buds was not affected when $g c l$ levels were reduced because of the maternal expression of anti-sense gcl RNA (Jongens et al. 1992), overexpression of $\mathrm{gcl}$ causes the formation of supernumerary pole cells by initiating the formation of additional pole buds. In addition, the ectopic placement of gcl resulted in the initiation of ectopic pole buds at the anterior pole of the embryo. Thus, gcl must function before or during the initiation of pole bud formation. It is possible that the levels of $g c l$ were not reduced sufficiently in the embryos with maternal expression of antisense gcl RNA to cause an effect on pole bud formation. The level of $g c l$ activity required for the induction of pole bud formation may be much less than that required to complete pole cell formation, which was affected in these embryos (Jongens et al. 1992). To determine more accurately the earliest point at which $\mathrm{gcl}$ acts in this pathway, we are currently screening for null mutations in the $g c l$ gene.

\section{The distribution of gcl protein and the mechanism by which it may initiate the germ-cell specification pathway}

The subcellular localization of gcl protein is rather intriguing. Our analysis using both high-resolution threedimensional wide-field microscopy and immunoelectron microscopy indicate that the majority of gcl protein is localized near NPCs. The gcl gene thus encodes the first example of a cell type-specific nuclear pore-associated protein. In addition, the distribution of gcl protein with respect to nuclear pores is novel, in that it is the only known example of a protein that localizes, with such a variable distribution, to the nucleoplasmic side of the nuclear pore.

We do not know what localizes gcl protein near nuclear pores. One possibility is that gcl binds to components of the "basket" structure located on the nucleoplasmic side of the NPC. Ultrastructural analysis of the NPC has revealed a highly organized basket structure formed by filaments that emanate from the nucleoplasmic surface and extend $\sim 100 \mathrm{~nm}$ toward the nucleoplasm where they attach to a ring-like structure (Jarnik and Aebi 1991; Ris 1991; Akey and Radamacher 1993). The preservation of the basket structure is known to be highly dependent on fixation conditions; under many fixation conditions it may appear as a less ordered array of filaments, or may not be visible, because of its collapse or loss during sample preparation (Gerace 1992). The general localization of gcl protein to within $100 \mathrm{~nm}$ of the nucleoplasmic surface of a nuclear pore, its variable positioning with respect to pores, and lack of association with all identifiable pores, are consistent with the variability in localization expected for a protein associated with the basket structure.

The localization of gcl protein to the vicinity of the nuclear pore, and its specificity to the pole cell nuclei suggest a possible role in regulating nuclear trafficking. One way gcl may function is by controlling access of germ-cell determinants to a limited number of nuclei at the posterior pole. Alternatively gcl could block nuclear 
import or export in a way required for germ-cell determination. The limiting level of gcl may thus determine the number of pole cell nuclei that can arise in the syncytial embryo. In considering the specific import or export block model, it is interesting to note that the pole cell nuclei contain a unique organelle referred to as the nuclear body (Mahowald et al. 1979). Because of morphologic similarity, nuclear bodies have been proposed to consist of polar granule material (Mahowald et al. 1979). In fact, like polar granules, they have been shown to contain vasa protein (Hay et al. 1988a). Nuclear bodies are detected in pole cells as soon as they form. These structures increase in number and size, then begin to fragment and disappear at stage $11(6.5 \mathrm{hr})$ (Mahowald et al. 1979|. Interestingly, the appearance and loss of gcl protein closely brackets the appearance and disappearance of the nuclear bodies (Jongens et al. 1992).

Results from Raff and Glover (1989) suggest that nuclei are not required to induce the formation of pole cells. They found that anucleate pole cell-like cells formed when DNA synthesis was blocked during the cleavage stages of embryogenesis. The formation of these pole cell-like cells was initiated presumably by centrosomes that, in the absence of nuclei, replicated and migrated into the pole plasm. At present we do not know how to reconcile these results with the localization of gcl near nuclear pores and its requirement for pole cell formation. Possibily there is an alternate pathway by which the formation of pole cells can be initiated, in the absence of nuclei.

\section{Requirements for the establishment of the germ line}

The results from this study indicate that $\mathrm{gcl}$ activity alone is not sufficient for pole cell formation or maintenance. Therefore, at least one other pole plasm component is required for these processes. In the case of $\mathrm{gcl}$ overexpression, there could be enough of this additional factor in the pole plasm to allow the formation of more pole cells, but not enough to maintain or fully establish pole cell identity. This additional factor, like $\mathrm{gcl}$, could be present at background levels throughout the rest of the embryo, so as to allow ectopically localized $\mathrm{gcl}$ to initiate some events of pole cell formation.

In addition to $g c l$, we know of seven other genes that encode pole plasm components and could be involved in pole cell formation or maintenance loskar, Ephrussi et al. 1991; Kim-Ha et al. 1991; vasa, Hay et al. 1988b; Lasko and Ashburner 1988; tudor, Bardsley et al. 1993; cyclin B, Whitfield et al. 1989; Lehner and O'Farrell 1990; orb, Lantz et al. 1992; mitochondrial lrRNA, Kobayashi et al. 1993; hsp83, Ding et al. 1993). The products of oskar, vasa, and tudor clearly have a role in organizing the germ-cell determinants (for review, see Ding and Lipshitz 1993; Lehmann and Rongo 1993; Wilson and Macdonald 1993|. It is conceivable that they may also have functions specifically required for pole cell formation (Ephrussi and Lehmann 1992; Smith et al. 1992; Bardsley et al. 1993). The ability of mitochondrial lrRNA to rescue pole cell formation in UV-treated embryos implies a role of mitochondrial functions in pole cell formation (Kobayashi and Okada 1989). In addition to these known pole plasm components, products of the agametic gene may also be pole plasm components as the maternal contribution of this gene is implicated in pole cell maintenance (Engstrom et al. 1982). It will be informative to investigate which of these or other as yet unidentified pole plasm components when ectopically colocalized with $\mathrm{gcl}$ will enhance the transformation toward pole cell fate.

\section{Material and methods}

Construction of hg and hgb transformant lines

$\mathrm{gcl}$ genomic sequences were obtained from an $11.0-\mathrm{kb}\{\mathrm{Clal}\}$ fragment contained in pBluescript (pgcl gen. \#1). The hsp83 promoter sequences were derived from a Dm 4.46. The 3' UTR sequences of bicoid mRNA were derived from pbcd 3' UTR . The hgb construct was made by replacing the gcl 3' UTR with a portion of the bcd 3'UTR. $\mathrm{gcl}$ genomic sequences from PmlI (+1936, 6 bp downstream of the $g c l$ stop codon) to ApaI (polylinker site) were replaced with the MluI-ApaI sequences from pbcd 3'UTR [downstream of the nanos response element site; Wharton and Struhl (1991)], but containing the anterior Iocalization signal and poly(A) site of bicoid (Macdonald and Struhl 1988), making the construct pgcl-bcd. A unique SpeI site was engineered at +3 of $g c l$ using site-directed mutagenesis. The hsp 83 promoter sequences from -880 (an engineered NotI site) to +15 (BsiWI) were introduced into pgcl-bcd after digestion with NotI and SpeI. The hg construct was made by replacing the BamHI-ApaI fragment $(+238$ to the polylinker of $\mathrm{pgcl}-b c d)$ with BamHI-ApaI sequences $(+238$ to $\sim 1.0 \mathrm{~kb}$ downstream of gcl) from $g c l$ gen.\#1. Both constructs were inserted between P-element ends of pW8 (Thummel et al. 1988) using the unique NotI and ApaI sites flanking the constructs and digesting pW8 with NotI and XhoI. Transgenic lines were obtained using standard techniques (Spradling 1986).

\section{Fly stocks}

The host for all of the transgenic experiments with the hg and hgb constructs is $w^{-}$and is described in Lindsley and Zimm (1992). The hgb construct was introduced into several posterior group mutant backgrounds using the following balancer $y w ; B c$, Elp/CyO; Ki/TM6, Ubx constructed by Ellsworth Grell. The following posterior group mutants were used in this study: cap-

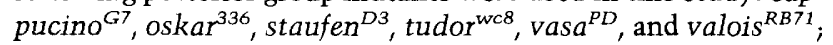
as well as the following fly stocks: $B i c D^{7134} / B i c D^{E I I I 48}, b c d^{E 1}$ (Lindsley and Zimm 1992) and (nanos/bicoid) n-b2-4 (Gavis and Lehmann 1992).

\section{Immunocytochemistry and in situ hybridization}

The procedure for antibody staining and in situ hybridization of whole-mount embryos was described previously (Bodmer and Jan 1987; Jongens et al. 1992). Anti-vasa monoclonal mAb46F11, purified from ascites, was used at a concentration of 1:500. Anti-gcl antibody prepared as described in Jongens et al. (1992) was used at a concentration of 1:2000. Comparative antibody stainings and whole-mount in situ hybridizations were done by fixing, staining, and developing the staining reactions for several preparations in parallel; all such reactions were initiated and terminated at the same time. 


\section{Pole cell counts}

Pole cell counts of cellular blastoderm and stage 14 embryos were made using 0 - to $4-\mathrm{hr}$ and 8- to 12 -hr collections, respectively, which were fixed and stained with anti-vasa or anti-gcl antibodies (Hay et al. 1988a; Jongens et al. 1992). The "cellular blastoderm" stage counts were performed on embryos that had initiated or just completed cellularization. Stage 14 embryos were identified based on embryonic gut and anterior morphology and the coalescence of pole cells in the embryonic gonad. The pole cells were counted as in Jongens et al. (1992).

Pole cell counts at the time of pole cell formation were made on 0 - to 3-hr embryo collections stained with anti-vasa antibody followed by a fluorescently labeled secondary antibody and Hoescht $(1.0 \mu \mathrm{g} / \mathrm{ml})$. Pole cell counts were made on embryos that were between interphase and mitosis of nuclear cycle 11 . Embryos were determined to be at nuclear cycle 11 based on nuclear density at the periphery and completion of cytokinesis at the posterior pole. Only completely formed cells that stained positive with vasa antibodies were counted.

\section{Analysis of nuclear divisions}

To analyze nuclear divisions and nuclear size, we fixed embryo collections and stained them with Hoescht. Pole bud nuclei were scored as delayed in their nuclear divisions if the majority of the pole bud nuclei were still in metaphase or prophase when all of the somatic-destined nuclei were at or beyond anaphase. The compaction of the nuclei was determined by comparing the diameter of the nuclei in pole buds to the diameter of somaticdestined nuclei at the lateral, anterior, and posterior positions of the embryo. A binary $z$-score was calculated to determined if the observed frequencies of size difference and mitotic asynchrony between the pole bud and somatic nuclei were statistically significant. A $z>2.58$ indicates a $>99 \%$ probablity that the data are significantly different. The hgb embryos were analyzed similarly, except that the anterior nuclei were compared to the somatic nuclei in the posterior two-thirds of the embryo.

To analyze nuclear divisions in living embryos, bleach dechorionated embryos were mounted on coverslips and covered with a 1:1 mix of $3 \mathrm{~S}$ and $7 \mathrm{~S}$ of Voltalef oil. Nuclear divisions were observed at the periphery of the embryos using a $40 \times$ objective, immersed in the Voltalef oil, in conjunction with DIC optics. Mitotic waves were either observed using time-lapse CCD photoimagery or manual observation.

\section{Northern analysis}

For comparison of gcl levels between the control (host line) and hg embryos, RNA was prepared from 0 - to 1 -hr collections and analyzed by Northern analysis and quantitated as described previously (Jongens et al. 1992).

\section{High-resolution three-dimensional wide-field analysis of the subcellular localization of $\mathrm{gcl}$}

Embryos were fixed and stained with both anti-gcl and antilamin monoclonal antibodies as described above. Three-dimensional images of immunostained embryos were recorded using a CCD-based imaging system. For design and specifications of the system, see Hiraoka et al. (1991) and Kam et al. (1993). Optical sections $(512 \times 512$ pixels; effective pixel size $=0.0744 \mu \mathrm{m})$ were recorded with an Olympus Plan ApoChromat 60×/NA1.4 lens at $0.2-\mu \mathrm{m}$ intervals by changing the microscope focus with a computer-controlled Nanomover motor (Melles Griot, Inc., Rochester, NY). Multiple wavelength three-dimensional images were recorded in a single focal series through a multipass dichroic mirror (Chroma Technology Inc., Brattleboro, VT) by alternating the appropriate bandpass excitation and emission filters for fluorescein isothiocyanate and Texas red /Chroma Technology Inc.) at each focal plane. Iterative, constrained, three-dimensional deconvolution was then used to remove out-of-focus information in the images (Agard et al. 1989; Hiraoka et al. 1991). This technique deblurs an image by moving out-of-focus intensity back to its originating point based on an empirical measure of the "point-spread" function, the blurring of an image caused by the limited resolution of the objective lens. Projections through selected regions of the data stack were calculated as described previously (Agard et al. 1989).

\section{Immunoelectron microscopic analysis of gcl protein distribution}

Blastoderm-stage embryos were dechorionated with sodium hypochlorite $(0.5 \times$ bleach $)$, rinsed with $\mathrm{ddH}_{2} \mathrm{O}$, and prefixed in a 1:1 mix of heptane: $0.1 \mathrm{M} \mathrm{NaPO}_{4}(\mathrm{pH} 7.2)$ with $4 \%$ formaldehyde (EM grade, Polysciences) and $0.02 \%$ glutaraldehyde (EM grade, Ted Pella Inc.) on a rotary mixing table at $300 \mathrm{rpm}$ for 30 min at room temperature. The embryos were transfered to a 1:1 mix of heptane: $1 \times$ PBS, then hand devitellinized by rubbing between a frosted end of a slide and a cover slip. Completely devitelinized embryos were obtained as they drop through the heptane: $1 \times$ PBS interface. The devitellinized embryos were then permeabilized and blocked with $1 \times$ PBS containing $5 \%$ normal goat serum, $2 \% \mathrm{BSA}, 2 \mathrm{mg} / \mathrm{ml}$ glycine, and $0.05 \%$ saponin for $15 \mathrm{~min}$ at room temperature. The antibody staining was carried out as described above, except that the anti-gcl antibody was used at a concentration of $1: 200$ or $1: 500$ in $1 \times$ PBS, $5 \%$ normal goat serum, $2 \% \mathrm{BSA}$ for $3 \mathrm{hr}$ at room temperature. Anti-gcl antibody was omitted in an aliquot of embryos that were processed in parallel to determine the gcl-dependant signal. The localization of label along the nuclear envelope was anti-gcl dependent. The embryos were washed three times for $10 \mathrm{~min}$, three times for $30 \mathrm{~min}$, and then stained with a goat $\mathrm{F}\left(\mathrm{ab}^{\prime}\right) 2$ anti-rabbit coupled to $1.4-\mathrm{nm}$ gold particles (Nanoprobes) for $3 \mathrm{hr}$ at room temperature. After the secondary antibody reaction and washing, the embryos were rinsed three times for $5 \mathrm{~min}$ in $0.1 \mathrm{M}$ sodium phosphate ( $\mathrm{pH} 7.2$ ), then postfixed in $0.1 \mathrm{~m}$ sodium phosphate $(\mathrm{pH} 7.2)$ with $4 \%$ formaldehyde and $2 \%$ glutaraldehyde, for $1 \mathrm{hr}$ at room temperature. The $1.4-\mathrm{nm}$ gold label was enhanced using an $N$-propyl gallate silver lactate enhancement for 8-20 min., followed by neutral fixer (Burry et al. 1992). The embryos were then rinsed with $0.1 \mathrm{M} \mathrm{NaPO}_{4}(\mathrm{pH} 7.2)$ twice for $5 \mathrm{~min}$, twice in $0.1 \mathrm{M}$ sodium cacodylate $(\mathrm{pH} 7.2)$ for 5 min, then fixed with $0.1 \% \mathrm{OsO}_{4}$ for $30 \mathrm{~min}$ and rinsed with 0.1 $M$ sodium cacodylate $(\mathrm{pH} 7.2)$. The embryos were then dehydrated in an ethanol series three times at $35 \%, 70 \%, 95 \%$, and $100 \%$. Propylene oxide was used as a transitional fluid to EmBed epoxy resin (Polysciences). Subsequent to polymerization at $60^{\circ} \mathrm{C}$ for $48 \mathrm{hr}$ between two microscope slides coated with dimethyl dichlorosilane, individual embryos were selected and mounted on a blank epoxy block with cyanocrylate adhesive. Sections $(100-\mathrm{nm})$ were cut, then stained with $2 \%$ aqueous uranyl magnesium acetate and lead citrate. Specimens were examined and photographed at $80 \mathrm{kV}$.

\section{Acknowledgments}

We thank John Lis for the hsp 83 subclone, aDm 4.46; Elizabeth Gavis and Ruth Lehmann for the nanos-bicoid transformant stock n-b2-4; Vivian Siegel for the pbcd 3' UTR subclone; Pat- 
rick O'Farrell for the use of his DIC and CCD microscopes; Ilan Davis for instruction and advice on the use of the CCD microscope for live recordings; David A. Agard and John W. Sedat for use of their wide-field fluorescence microscope and imaging and electron microscope facilities; Sandra Barbel and William Walantus for help in preparing figures; all of the Jan laboratory members who made critical and helpful suggestions during the course of this work, especially Vivian Siegel and Ira Clark for many enlightening discussions and for critical reading and helpful suggestions on the manuscript. We thank Deborah Finley for an introduction into the field of nuclear pores, for many helpful suggestions, and for interest in our results. T.A.J. is a Howard Hughes Associate; L.Y.J and Y.N.J. are Howard Hughes Investigators.

The publication costs of this article were defrayed in part by payment of page charges. This article must therefore be hereby marked "advertisement" in accordance with 18 USC section 1734 solely to indicate this fact.

\section{References}

Agard, D.A., Y. Hiraoka, P. Shaw, and J.W. Sedat. 1989. Fluorescence microscopy in three dimensions. Methods Cell Biol. 30: 353-377.

Akey, C.W. and M. Radermacher. 1993. Architecture of the Xenopus nuclear pore complex revealed by three-dimensional cryo-electron microscopy. I. Cell Biol. 122: 1-19.

Aris, J.P. and G. Blobel. 1989. Yeast nuclear envelope proteins cross react with an antibody against mammalian pore complex proteins. I. Cell Biol. 108: 2059-2067.

Bardsley, A., D. McDonald, and R.E. Boswell. 1993. Distribution of tudor protein in the Drosophila embryo suggests separation of functions based on site of localization. Development 119: 207-219.

Barker, D.D., C. Wang, J. Moore, L.K. Dickinson, and R. Lehmann. 1992. pumilio is essential for function but not for distribution of the Drosophila abdominal determinant nanos. Genes \& Dev. 6: 2312-2326.

Beams, H.W. and R.G. Kessel. 1974. The problem of germ cell determinants. Int. Rev. Cytol. 39: 413-479.

Belmont, A.S., Y. Zhai, and A. Thilenius. 1993. Lamin B distribution and association with peripheral chromatin revealed by optical sectioning and electron microscopy tomography. J. Cell Biol. 123: 1671-1685.

Berleth, T., M. Burri, G. Thoma, D. Bopp, S. Richstein, G. Frigerio, M. Noll, and C. Nüsslein-Volhard. 1988. The role of localization of bicoid mRNA in organizing the anterior pattern of the Drosophila embryo. EMBO J. 7: 1749-1756.

Bodmer, R. and Y.N. Jan. 1987. Morphological differentiation of the embryonic peripheral neurons in Drosophila. Wilhelm Roux's Arch. Dev. Biol. 196: 69-77.

Boswell, R.E. and A.P. Mahowald. 1985. tudor, a gene required for assembly of the germ plasm in Drosophila melanogaster. Cell 43: 97-104.

Boswell, R.E., M.E Prout, and J.C. Streichen. 1991. Mutations in a newly identified Drosophila melanogaster gene, mago nashi, disrupt germ cell formation of mirror-image symmetrical double abdomen embryos. Development 113: 373-384.

Burry, R.W., D.P. Vandre, and D. Hayes. 1992. Silver enhancement of gold antibody probes in pre-embedding electron microscopic immunocytochemistry. $J$. Histochem. Cytochem. 40: $1849-1856$.

Davis, L.I. and G. Blobel. 1986. Identification and characterization of a nuclear pore complex protein. Cell 45: 699-706.

Davis, L.I. and G.R. Fink. 1990. The NUP1 gene encodes an essential component of the yeast nuclear pore complex protein. Cell 61: 965-978.

Ding, D. and H.D. Lipshitz. 1993. Localized RNAs and their functions. BioEssays 15: 651-658.

Ding, D, S.M. Parkurst, S.R. Halsell, and H.D. Lipshitz. 1993. Dynamic Hsp83 RNA localization during Drosophila oogenesis and embryogenesis. Mol. Cell. Biol. 13: 3773-3781.

Dingwall, C. and R.A. Laskey. 1992. The nuclear membrane. Science 258: 942-947.

Driever, W. and C. Nüsslein-Volhard. 1988. The bicoid protein determines position in the Drosophila embryo in a concentration-dependent manner. Cell 54: 95-104.

Eddy, E.M. 1975. Germ plasm and the differentiation of the germ cell line. Int. Rev. Cytol. 43: 229-280.

Engstrom, E., J.H. Caulton, E.M. Underwood, and A.P. Mahowald. 1982. Developmental lesions in the agametic mutant of Drosophila melanogaster. Dev. Biol. 91: 163-170.

Ephrussi, A. and R. Lehmann. 1992. Induction of germ cell formation by oskar. Nature 538: 387-392.

Ephrussi, A., L.K. Dickinson, and R. Lehmann. 1991. oskar organizes the germ plasm and directs localization of the posterior determinant nanos. Cell 66: 37-50.

Finlay, D.R., D.D. Newmeyer, T.M. Price, and D.J. Forbes. 1987. Inhibition of in vitro nuclear transport by a lectin that binds to nuclear pores. I. Cell Biol. 104: 189-200.

Foe, V.E., G.M. Odell, and B.A. Edgar. 1993. Mitosis and morphogenesis in the Drosophila embryo: Point and counterpoint. In The development of Drosophila melanogaster led. M. Bate and A. Martinez Arias), pp.149-300. Cold Spring Harbor Laboratory Press, Cold Spring Harbor, New York.

Frohnhöfer, H.G. and C. Nüsslein-Volhard. 1986. Organization of anterior pattern in the Drosophila embryo by the maternal gene bicoid. Nature 324: 120-125.

Fullilove, S.L. and A.G. Jacobson. 1971. Nuclear elongation and cytokinesis in Drosophila montana. Dev. Biol. 26: 560-577.

Gavis, E. and R. Lehmann. 1992. Localization of nanos RNA controls embryonic polarity. Cell 71: 301-313.

Gerace, L. 1992. Molecular trafficking across the nuclear pore complex. Curr. Opin. Cell. Biol. 4: 637-645.

Hay, B., L. Ackerman, S. Barbel, L.Y. Jan, and Y.N. Jan. 1988a. Identification of a component of Drosophila polar granules. Development 103: 625-640.

Hay, B., L.Y. Jan, and Y.N. Jan. 1988b. A protein component of the Drosophila polar granules is encoded by vasa and has extensive sequence similarity to ATP-dependent helicases. Cell 55: 577-587.

- 1990. Localization of vasa, a component of Drosophila polar granules, in maternal-effect mutants that alter embryonic anteroposterior polarity. Development 109: 425-433.

Hiraoka, Y., J.R. Swedlow, M.R. Paddy, D.A. Agard, and J.W. Sedat. 1991. Three-dimensional multiple-wavelength fluorescence microscopy for the structural analysis of biological phenomena. Sem. Cell Biol. 2: 153-165.

Illmensee, K. and A.P. Mahowald. 1974. Transplantation of posterior pole plasm in Drosophila: Induction of germ cells at the anterior pole of the egg. Proc. Natl. Acad. Sci. 7: 1016 1020.

Jarnik, M. and U. Aebi. 1991. Toward a more complete 3-D structure of the nuclear pore complex. J. Structural Biol. 107: 291-308.

Jongens, T.A., B. Hay, L.Y. Jan, and Y.N. Jan. 1992. The germ cell-less gene product: A posteriorly localized component necessary for germ cell development in Drosophila. Cell 70: 569-584.

Kam, Z., M.O. Jones, H. Chen, D.A. Agard, and J.W. Sedat. 1993. Design and construction of an optimal illumination system 
for quantitative wide-field multi-dimensional microscopy. BioImaging 1: 71-81.

Kim-Ha, J., J.L. Smith, and P.M. MacDonald. 1991. oskar mRNA is localized to the posterior pole of the Drosophila oocyte. Cell 66: 23-35.

Kobayashi, S. and M. Okada. 1989. Restoration of pole-cellforming ability to u.v.-irradiated Drosophila embryos by injection of mitochondrial lrRNA. Development 107: 733742.

Kobayashi, S., R. Amikura, and M. Okada. 1993. Presence of mitochondrial large ribosomal RNA outside mitochondria in germ plasm of Drosophila melanogaster. Science 260: 1521-1524.

Lantz, V., L. Ambrosio, and P. Schedl. 1992. The Drosophila orb gene is predicted to encode sex-specific germline RNA-binding proteins and has localized transcripts in ovaries and early embryos. Development 115: 75-88.

Lasko, P.F. and M. Ashburner. 1988. The product of the Drosophila gene vasa is very similar to eukaryotic initiation factor-4A. Nature 335: 611-617.

1990. Posterior localization of vasa protein correlates with, but is not sufficient for, pole cell development. Genes \& Dev. 4: 905-921.

Lehmann, R. and C. Nüsslein-Volhard. 1986. Abdominal segmentation, pole cell formation and embryonic polarity require the localized activity of oskar, a maternal gene in Drosophila. Cell 47: 141-152.

-1987. Involvement of the pumilio gene in the transport of an abdominal signal in the Drosophila embryo. Nature 329: $167-170$

- 1991. The maternal gene nanos has a central role in posterior pattern formation of the Drosophila embryo. Development 112: 679-693.

Lehmann, R. and C. Rongo. 1993. Germ plasm formation and germ cell determination. Sem. Dev. Biol. 4: 149-159.

Lehner, C.F. and P.H. O'Farrell. 1990. The roles of Drosophila cyclins A and B in mitotic control. Cell 61: 535-547.

Lindsley, D.L. and G.G. Zimm. 1992. The genome of Drosophila melanogaster. Academic Press, San Diego, CA.

Macdonald, P.M. 1992. The Drosophila pumilio gene: An unusually long transcription unit and an unusual protein. $D e$ velopment 114: 221-232.

Macdonald, P.M. and G. Struhl. 1988. Cis-acting sequences responsible for anterior localization of bicoid mRNA in Drosophila embryos. Nature 336: 595-598.

Mahowald, A.P. 1962. Fine structure of pole cells and polar granules in Drosophila melanogaster. J. Exp. Zool. 151: 201216.

- 1971. Polar granules in Drosophila. IV. Cytochemical studies showing a loss of RNA from polar granules during early stages of embryogenesis. J. Exp. Zool. 176: 345-352.

Mahowald, A.P., C.D. Allis, K.M. Karrer, E.M. Underwood, and G.L. Waring. 1979. Germ plasm and pole cells of Drosophila. In Determinants of spatial organization (ed. S. Subtelny and I.R. Konigsberg), pp. 127-146. Academic Press, New York.

Manseau, L.J. and T. Schüpbach. 1989. cappucino and spire: Two unique maternal-effect loci required for both the anteroposterior and dorsalventral patterns of the Drosophila embryo. Genes \& Dev. 3: 1437-1452.

Marsh, L., A.M. Neiman, and I. Herkowitz. 1991. Signal transduction during pheromone response in yeast. Annu. Rev. Cell Biol. 7: 699-728.

Mohler, J., and E.F. Wieschaus. 1986. Dominant maternal-effect mutations of Drosophila melanogaster causing the production of double-abdomen embryos. Genetics 112: 803-822.

Nehrbass, U., H. Kern, A. Mutvei, H. Horstmann, B. Marshall- say, and E.C. Hurt. 1990. NSP1: A yeast nuclear envelope protein localized at the nuclear pores exerts its essential function by its carboxy-terminal domain. Cell 61: 979-989.

Niki, Y. 1986. Germline autonomous sterility of P-M dysgenic hybrids and their application to germline transfers in Drosophila melanogaster. Dev. Biol. 113: 255-258.

Olson, E.N. 1992. Interplay between proliferation and differentiation within the myogenic lineage. Dev. Biol. 154: 261272.

Raff, J.W. and D.M. Glover. 1989. Centrosomes, and not nuclei, initiate pole cell formation in Drosophila embryos. Cell 57: 611-619.

Ris, H. 1991. The three-dimensional structure of the nuclear pore complex as seen by high voltage electron microscopy and high resolution low voltage scanning electron microscopy. EMSA Bull. 21: 54-56.

St. Johnston, D., D. Beuchle, and C. Nüsslein-Volhard. 1991. staufen, a gene required to localize maternal RNAs in the Drosophila egg. Cell 66: 51-63.

Schüpbach, T. and E. Wieschaus. 1986. Maternal-effect mutations altering the anterior-posterior pattern of the Drosophila embryo. Wilhelm Roux's Arch. Dev. Biol. 195: 302317.

Siegel, V., T.A. Jongens, L.Y. Jan, and Y.N. Jan. 1993. pipsqueak, an early acting member of the posterior group of genes, affects vasa level and germ cell-somatic cell interaction in the developing egg chamber. Development 119: 1187-1202.

Smith, J.L., J.E. Wilson, and P.M. Macdonald. 1992. Overexpression of oskar directs ectopic activation of nanos and presumptive pole cell formation in Drosophila embryos. Cell 70: 849-859.

Spradling, A.C. 1986. P-element mediated transformation. In Drosophila: A practical approach (ed. D.B. Roberts), pp. 175197. IRL Press, Oxford, UK.

Technau, G.M. and J.A. Campos-Ortega. 1986. Lineage analysis of transplanted individual cells in embryos of Drosophila melanogaster. III. Commitment and proliferation capabilities of pole cells and midgut progenitors. Wilhelm Roux's Arch. Dev. Biol. 195: 489-498.

Thummel, C.S., A.M. Boultet, and H.D. Lipshitz. 1988. Vectors for Drosophila P element-mediated transformation and tissue culture transfection. Gene 74: 445-456.

Turner, F.R. and A.P. Mahowald. 1976. Scanning electron microscopy of Drosophila embryogenesis. I. The structure of the egg envelopes and the formation of the cellular blastoderm. Dev. Biol. 50: 95-108.

Underwood, E.M., J.H. Caulton, C.D. Allis, and A.P. Mahowald 1980. Developmental fate of pole cells in Drosophila melanogaster. Dev. Biol. 77: 303-314.

Wang, C. and R. Lehmann. 1991. nanos is the localized posterior determinant in Drosophila. Cell 66: 637-647.

Wente, S.R., M.P. Rout, and G. Blobel. 1992. A new family of yeast nuclear pore proteins. $/$. Cell Biol. 119: 705-723.

Wharton, R.P. and G. Struhl. 1991. RNA regulatory elements mediate control of Drosophila body pattern by the posterior morphogen nanos. Cell 67: 955-967.

Whitfield, W.G.F., C. Gonzalez, E. Sanchez-Herrero, and D.M. Glover. 1989. Transcripts of one of two Drosophila cyclin genes becomes localized in pole cells during embryognensis. Nature 338: 337-340.

Wilson, J.E. and P.M. Macdonald. 1993. Formation of germ cells in Drosophila. Curr. Opin. Genet. Dev. 3: 562-565.

Xiao, H. and J.T. Lis. 1989. Heat shock and developmental regulation of the Drosophila melanogaster hsp83 gene. Mol. Cell. Biol. 9: 1746-1753. 


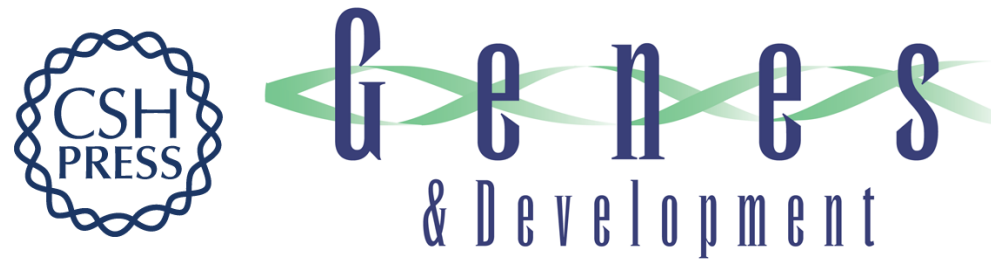

\section{Germ cell-less encodes a cell type-specific nuclear pore-associated protein and functions early in the germ-cell specification pathway of Drosophila.}

T A Jongens, L D Ackerman, J R Swedlow, et al.

Genes Dev. 1994, 8:

Access the most recent version at doi:10.1101/gad.8.18.2123

References This article cites 72 articles, 22 of which can be accessed free at:

http://genesdev.cshlp.org/content/8/18/2123.full.html\#ref-list-1

License

Email Alerting

Service

Receive free email alerts when new articles cite this article - sign up in the box at the top right corner of the article or click here.

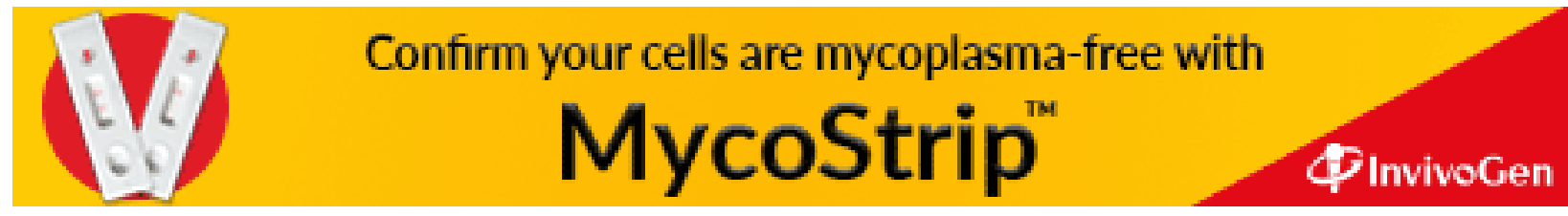

